\title{
THE NIGERIAN STEEL SECTOR IN THE GLOBAL STEEL INDUSTRY
}

\author{
Daniel A. Omoweh \\ Nigerian Institute of International Affairs Lagos, Nigeria.
}

\begin{abstract}
This paper examines the nature and process of the re incorporation of the Nigerian steel sector into the world capitalist steel industry, and analyses its Consequences for the country's deepening industrial backwardness. It argues that the Nigerian State has, on account of its capitalism, collaborated with the steel transnational corporations to undermine the country's steel sector It submits that unless the State rethinks both its approach to steel development and current strategy of industrialization, Nigeria's capacity to achieve autonomy $m$ technology development will remain a failure. The article is partially based on information observed/collected during the author's field trips to the DSC, the Steel Rolling Mills and some, capital goods producing companies.
\end{abstract}

\section{Introduction}

Dominated as it is by state-owned iron and steel companies that account precisely for 95 percent of its activities, the Nigerian steel industry has, in the past 15 years of coming on stream, failed woefully to lay the country's foundation for industrialization. As a result, the country's intermediate and capital industrial sector, which, itself, is an index of the level of steel and industrial development, remain largely dependent on imports for its basic raw materials. Per capita steel consumption, also a measure of a country's level of industrial development, has rather than rise, fallen from 80 kilograms in the 1970s, to 15 kilogram by the 1990s. So, too, has steel production as a percentage of total manufacturing, another index of industrial growth, never attained one percent. In terms of capacity utilization, the steel corn-panics have never exceeded an average of three percent of their installed capacities since inception. What is more, the absence of a strategic industrialization policy, both for the industrial sector and for iron and steel, has left the country's steel industry without any direction.

Nigeria is not the only country whose iron and steel sector is faced with crisis among other African steel producing countries. Other notable steel producers like Egypt, Algeria, Zimbabwe, Tunisia and Libya are equally faced with problems of declining per capita steel consumption, poor financing, and under capacity utilization, down-sizing though of lesser magnitude. In fact, it is a crisis that has afflicted the entire global steel industry since 1975, leaving the major capitalist steel producing countries like Japan, South Korea, Ger- 
many and France badly hit by shut down, and market gluts.

However, the crucial issue at stake is not really so much with the structural crisis facing the Nigerian steel sector as with its origin. The basic questions therefore, are: Did the crisis arise from the structural problems that set into the world steel industry since 1975 ? Or was it rooted largely in the state's mode of extracting surplus from the economy inclusive of the steel sector?

As its central theses, this paper argues that: (i) though steel development was not really on the agenda of the custodians of the Nigerian state, the country's early contact with the forces of imperialism during the era of British colonialism significantly disrupted its industrial development continuum; and (ii) the disruption of the country's primordial industrial base not only reincorporated its steel sector into the global steel industry, but was sustained through an alliance between the state and the forces of transnational capitalism. Let us now elaborate on these hypotheses,, beginning with how the country's steel industry was undermined by the steel transnational's.

\section{Nigeria's Steel Sector in the Global Capitalist Steel Industry}

Since Walter Rodney's treatise (1976), the rapid rate of regime perish ability, decadence of the state, corruption and economic stagnation across Africa have forced the majority of scholars of African political economy into reconsidering their earlier position of blaming Western Europe more or less solely for the continent's industrial, economic and political backwardness. On Nigeria's industrial backwardness in particular, researchers are still engaged in raging defaces as to why the country's steel sector has failed to reverse its trend of failure. Other scholars, particularly those working on the political economy of Nigeria, still contend that the evils of colonialism are irreparable and therefore blamed the country's industrial and economic backwardness solely on the forces of Western imperialism, especially the transnational corporations. Critics of this position think otherwise, arguing instead that though British colonialism laid the basis for the country's industrial failure, a lot more is really wrong with the nature of the postcolonial Nigerian State and its approach to industrialization. Citing the relative 'success story' of the 'Asian Tigers', they insist that Nigeria's industrial under development is largely self-inflicted, accusing the State as the chief culprit.

Neither of these scholarly positions has led Nigerian's iron and steel sector out of its current crisis; nor has any of them developed critical theoretical framework to deepen an understanding of the crisis in the country's steel industry. This section therefore, attempts to overcome these problems by redressing unsettled theoretical issues in the literature on the political economy of Nigeria's industrialization with emphasis on its steel sector. 
Contextualizing Reincorporation: Early underdevelopment and dependency theorists (UDT) like Baran (1957) and Frank (1976), have always argued that Western European colonialism 'blocked' the capability of former colonies in Latin America, Asia and Africa to promote 'proper' capitalist development. This philosophical premise was to influence the thinking of most scholars of the political economy of Nigeria. In employing the UDT paradigm for instance, Nnoli (1981 ed.) and other contributors blamed the country's industrial underdevelopment on the transnational corporations, advocating the expulsion of the transnational's as a condition for the reversal of the country's industrial and economic underdevelopment.

One is inclined to think otherwise since such an action may not necessarily mean the end of the process of the reincorporation of Nigeria into the global capitalist economy. For one thing, the nature of capitalist accumulation in the post-colonial Nigerian economy is a combination of the collaborative self-seeking interests of the managers of the Nigerian State, its groups and transnational capital which have undermined the capacity of the country's economy to sustain itself. And it is in the joint interest for accumulation without production of wealth by the State and its collaborators with transnational capital that lies the process of the reincorporation of the country's steel sector into the global steel industry. Far from being a class project and as a bedrock for the country's industrialization, those in charge of the Nigerian State only embarked upon steel development ostensibly to provide an avenue for the consumption of oil wealth. In essence, the nature of capitalist accumulation in the country's steel sector is on less than rent-seeking, a process that accommodates the economic interests of the steel transnational in order to reproduce itself.

The re-incorporation of the Nigerian steel sector into the global steel industry therefore, is a complex process particularly as the managers of the Nigerian State acquiesce to the dictates of the steel transnational's to enable them amass wealth. In no other area has this been more glaring than in the nature of state capitalism in the steel sector.

\section{Nature of State Capitalism in Nigeria's Steel Sector:}

What most worried Kilby (1969) about Nigeria's prospect for industrialization after the end of the WWII in 1945, was that the country had no industrial policy as of the 1960s and the chances of any emerging in the 1970s and beyond seemed very remote. Kilby is not an alarmist after all; for, his fear is confirmed particularly as the country still has no industrial policy by the 1990s Rather, what is in place are merely packages of industrial incentives designed to attract foreign 
capital. Little wonders why strategic as the iron and steel sector is to the industrial and technological growth of any country, not least Nigeria, no policy has guided its establishment and operations till date. The lack of a steel development policy in Nigeria is a precipitate of the nature of State capitalism in the economy.

However, it is not to argue that the absence of such a strategic industrial policy meant that some form of industrialization has not been encouraged in the country by the State, local private capital, arid the transnational's. Far from it. After all, the country's steel sector came on stream in the early 1980s even without any policy. But the basic questions still remain: Has the onset of the steel companies really created the local capability to endogenize technology that will reverse, and if possible, halt the country's deepening industrial backwardness? On whose behalf did the state really intervene into the steel sector? It is only with an understanding of the nature of state capitalism in the steel sector that useful insights can be gained into the process and mode of reintegration of the country's steel sector into the global steel industry, and the consequences for its industrial underdevelopment.

State capitalism is still fledging in the Nigerian steel sector as well as in other subsectors of the economy. All is to make it pretty difficult to sustain its earlier characterization by most scholars as either 'commercial' or 'parasitic'. Not even its inability to produce but only consume wealth which comes in the form of rent from oil production and export, makes it holistically 'rentier'. For, the state's mode of capitalist accumulation in the petroleum sector is still not strictly the same with that in the steel industries. For instance, while state capitalism is generally rent-seeking in the petroleum industry, in the steel sub-sector, it is slightly different. Encouraged by the windfall from crude oil export in the early 1970s, rather than consume all the earnings, the custodians of the State transformed part of the revenue into physical assets in the form of steel companies. Therefore, State capitalism in the steel industry is informed by the imperatives of installing structures for sustaining the accumulative base of its custodians, its allies, and the transnational's. In essence, the steel sector was not really on the agenda of industrial development. For, if it were, the steel sector would have ordered the direction of the country's industrial growth as evidenced by "late industrializes" like South Korea. What took place in the steel sector and is still so, is a mirror of the nature of the raging and d6ep-seated class war for amassing wealth between and among the various groups that make up the Nigerian State. One cannot but, agree with Yachir (1986) who summarized the contradictions that State capitalism has engendered in the steel sector of dependent economics, notably the oil exporting countries in Africa including Nigeria. According to him:

'The development of the steel industry proceeds within a regime of stale capitalism, based on an alliance between local 
monopoly, private capital and bureaucratic bourgeoisie... On the one hand, the state constitutes, in the conditions of a dependent economy, the necessary support for the expansion of local private capital. On the other hand, in the exercise of this objectively necessary function, the state machinery becomes simultaneously the basis of a bureaucratic bourgeoisie which want its snare in the management of the economy and society'

It is these contradictions, arising from State capitalism in the Nigerian steel sector, that have furthered its re-incorporation into the global steel industry. Some explanation is important here.

To start with, the custodians of the Nigerian state do not only preoccupy themselves largely with the grim struggle for the control and maintenance of political power by all means, they use political power as a key to wealth. The public steel companies were largely established to meet the latter objective: that is, the accumulative desire of those in charge of the state even though they pretended to be pursuing the industrial development of Nigeria. As a result, funding them was problematic right from the onset. Rather than use subventions allocated to the companies to manage them, they were in most cases, shared by the managers of the State through various portfolio contracts that were hardly executed. As of the end of 1983, that is, less than six months after taking off, the public steel companies were already mired in acute financial crisis. All was to compel the State to source for funds from foreign private capital and the multilateral financial institutions with which to complete the Ajaokuta Steel Company, manage the Delta Steel Company (DSC) located at Aladja - Warri, and the three Rolling Mills located at Katsina, Jos and Oshogbo.

The financial crisis that State capitalism was faced with in the steel sector provided ample opportunity for the steel transnational to further stifle the halfhearted efforts at steel development in Nigeria since they were opposed to any major integrated steel company being established in the country. Beyond serving as a steel market, the steel transnational's have no real interest in Nigeria. Acting as a group, and under the aegis of the World Bank and the International Monetary Fund's multilateral financial assistance, the steel transnational's together with the Bank and the Fund, imposed stringent conditions for any form of loan to the crumbling public steel companies in Nigeria. The Bank and Fund insisted on the embracement of their adjustment package by the Nigerian government, and in which they demanded for me reduction of the country's total installed capacity of the steel companies from 5 million metric tonnes of crude steel yearly, to one million 


\section{Annals of the Social Science Council of Nigeria, No. 9, January-December 1997}

metric tonnes, a move calculated to reserve the country's huge steel market for the steel TNCs. They also demanded that the production of iron ore and steel should be basically meant for export; and finally, that the state should have no business in iron and steel development insisting therefore, on its total retrenchment (Hatch Report, 1988).

Implementing these corditionalities by the State would have amounted to the deepening dependence of the country's steel sector on the world steel industry. But the refusal of the State to tow the line of the Bank and Fund has not helped matters either. For, State capitalism in the steel sector is still influenced and manipulated by the steel transnational's and the multilateral financial institutions. The contradictions arising from the structural crisis in the contemporary global steel industry is to further dim the prospect of recovery for the Nigerian steel sector as it plunges deeper into the world steel industry. Let us examine the contradictions in the contemporary global steel industry as background to a deeper understanding of the crisis in Nigeria's steel sector.

\section{Contradictions in the Contemporary World Steel Industry}

The contemporary structure of the world steel industry emerged in 1975 following the loss of the premier position enjoyed by the leading traditional European iron and steel-producing and exporting countries namely Britain. France. Germany, Belgium, Italy, and later the Asian Pacific countries of Japan and South Korea. It was a loss that had its origin in the acute structural crises which bedeviled the global steel industry since the late 1960s: crisis of drastic fall in production output, declining investment, closure of more production lines, rising rate of downsizing, and obsolete machines and technologies. These crises would have been averted if the majority of the steel companies had, at the stage of market maturity of their steel sectors, diversified into non-steel sectors like semi-conductor as Japan did when its steel industry attained that height in the late 1970s. So, what are the origins and causes of the structural crises in the world steel industry?

In the one and a half decades following the end of the WWII in 1945. the global steel market witnessed a boom due in part to the increased demand for steel products for the reconstruction and rehabilitation of parts of war-torn Europe. The rise in the demand for steel products was also to meet the demand of other industrial purposes like ship building. Germany, which before the outbreak of WW II ranked as the leading European steel producer and exporter, had its steel sector looted by the British with which it was twice at war. In the immediate post-1945 period, however, it resuscitated its steel industry. By the turn of the 1970s, the German steel sector had been brought back to its former leading position as the largest steel producing and exporting country in Europe. Notable German steel transnational's like Krupp, Thyssen, and Klockner accounted for over a third of the 
total output of crude steel production in the European Community: 115.5 and 115 million metric tonnes in 1973, and 1975 respectively (Metal Bulletin, 1976). France, too, experienced early post-war expansion in steel development with Unisor, Sacilor among other steel transnational, takes the lead. The same was true of both Italy and Belgium. Much of the steel produced by the socialist economies of China and then USSR did not really enter into the global capitalist steel market: though they had experienced reasonable post-1945 growth and expansion in their steel sector, the impact was and is still not necessarily felt in the Euro-American steel industry. For the United States of America, its steel industry took-off ostensibly to meet its domestic demand for steel products: in essence, whatever growth it might have recorded in the immediate postWWII period, the export drive was still absent. But it was the same inward-looking steel development policy of the U.S that was to constitute a major problem for the chronic unfavourable balances of trade and payment that its steel industry was to face later. This it could not resolve even when it decided since the turn of the 1970s to extend the frontiers of its steel industry beyond the American shores. As a result, its steel market still remains a dumping ground for steel products mostly from the Japanese steel transnational (Metal Bulletin, 1978; 1980).

As the structural crises in the Euro-American steel industry deepened, Japan, without coal, iron ore and energy, had by 1975, emerged as the world largest steel producing and exporting country. With large steel transnational like Kobe Steel, Nishin Steel, Kawasaki Steel, Nippon Steel, Nippon Kokan, and Sumitomo, Japan produced an average of 70 million metric tonnes of crude steel yearly, a capacity beyond the reach of all steel companies in Europe and the U.S.A. put together. Furthermore, Japanese steel transnational had, by the late 1970s, bought over large reserves of iron ore, coal and alloying minerals in Latin American and parts of Asia; and have through joint venture and outright purchase, acquired and rehabilitated most of the ailing steel companies in the USA, Latin American and Asia (Metal Bulletin 1978; 1980).

However, the post-WWII growth in the global steel industry began to stagnate by the late 1970s since most of the repairs in the war-torn areas of Europe were already completed, leading to a decline in returns on investments, decreased per capita steel consumption, and excess capacity in the world steel industry. For instance, the total output of crude steel produced by the advanced capitalist countries notably USA, Japan, and EEC since 1973 had been on the decline and reached the lowest ebb in 1975. In 1973, the total output of crude steel was 372 million metric tonnes; it fell to 323.5 million metric tonnes in 1975; and rose slightly to 347 metric million tonnes in 1978, fell again to 327 million metric tonnes 1981, and dropped further to 290.5 million metric tonnes in 1985 (Metal Bulletin 1975; 1986). 


\section{Annals of the Social Science Council of Nigeria. No. 9. January-December,}

The trend since then has been a precipitous overall decline, though Japan's share of the total output still accounted for, over half. Save also Japan, which recorded the highest investment in the iron and steel industry in selected parts of the world since 1975, there was a general trend of de-investment. After an initial rise from a total of U\$\$10.5 billion in 1975, less investment capitals were committed in the remaining part of the decade: US\$8.6 billion in 1976, US\$6.6 billion in 1977, and 1978, US\$5.7 billion. The decline continued into the 1980s, and has become generally worse since then, though the Japanese and German steel industries, again, appeared relatively better off. The majority of the steel companies in the USA and the rest of Western Europe still remain in persistent structural crisis; an indication that the world steel industry is into a serious recession.

That is not all. The chronic perennial trade deficit that most steel TNCs were faced with, which for example, forced the British government to privatize British Steel (BS), is still deepening. Within the European Community too, a production ceiling was imposed on the steel transnational aimed at checking overproduction among member-countries, and if possible, halt dumping. Yet, the steel sector was to recover. In Japan, the steel giants have zoned production and product mix among themselves and even put a tab on new entry into a hitherto competitive industry. The American ailing steel companies were also unable to regenerate themselves as the protracted financial crisis continues to worsen.

From all appearances, the structural crises that had set into the global steel industry since 1975 still hindered new investment in the sector even by the turn of the 1990s. Given the huge funds that were already sunk into the industry so far, it is difficult to think of scrapping most of the companies and their major production lines. In addition to privatization as the British government did with the BS, the majority of the steel transnational's since then have resorted to measures that will keep them in operation pending the cessation of the structural crises. The bias for the production of special steel product was one of their strategies for survival since its demand was on the increase until the 1980s when it fell. The production of semi-finished steel products like billets and blooms for export to the emergent steel producing countries in Africa and the Middle East became the only most viable options for now. The steel TNCs also started relocating their steel rolling mills, which are end-product operations, to Africa where mini-steel companies are currently being set up. Most of the steel transnational's have equally resorted to contract-financing of small-capacity steel companies with the assurance that their investments are guaranteed by the government. Others use joint venture to sell their obsolete machines, equipment, and technologies. In fact, the majority of the steel transnational's are no less than vendors of outdated machines and raw materials. 
So, if there is any prospect for the global steel market, it lies outside of Europe and the USA - in Africa, Middle East and South East Asia. And this explains why the steel companies from both the western capitalist and socialist economies are all scrambling for the untapped huge steel market in Africa, and in the Middle East; a scramble that has come to dictate to a large measure, the type, pattern, and pace of growth and development of the steel industries in these regions. For instance, Qatar and Saudi Arabia operated joint venture with the Japanese and German steel companies that built their steel companies on turn-key, supplied the raw materials, and managed them. In Nigeria, on the other hand, the approach was slightly different in the sense that the conglomerate of steel transnational from Germany, Japan and Austria, merely got the contract to build all the public steel companies for the Nigerian government, the sole owner to manage. While the Nigerian government has really no plan for its steel companies, the Algerian government which had its public steel companies built by the steel transnational, recorded some success story in the steel sector, before it adjusted in the late 1980s, along with its religions crisis.

By and large, the steel TNCs from Europe and Japan still dictate the directions in which the steel sector in Africa, Asia and the Middle East is growing and how it is sustained. What are the implications of all these for Nigeria's steel development and industrialization?

\section{Deepening Crisis in the Nigerian Steel Sector and Implications for its Industrializations}

To begin with, colonial capitalism did not develop Nigeria's iron and steel sector for an obvious reason: to protect its steel market for the British steel companies. This was to further compound the problem of steel development by the post-colonial state even though it was not really on the agenda. Together, that is, both the forces of state and of transnational capitalism in the Nigerian steel sector have generated contradictions that have stifled the growth of the country's steel companies and other manufacturing concerns at large. Contradictions that manifest in the approach to steel development, linkage with other sectors of the economy, and finance. Some elaboration is ideal at this point.

\section{Absence of a Strategic Industrial Policy:}

Egypt, Algeria and Tunisia had, at the time they began to construct their steel industries in the 1950s and 1960s, set the steel sector within an industrialization policy framework that emphasized complimentarily between it and other 
sectors of the economy. Technological autonomy, therefore, was paramount in the industrial policy of each of these countries. In order to achieve this goal, the steel companies were equipped with components that produce flat, beams, angles, and special steel among other capital goods, which, in turn, are used as basic inputs by the heavy engineering companies to produce among others, machines, automobiles as well as their spare parts. That was how the steel sector was able to lay the bedrock of the relative industrial growth which these countries have recorded so far.

The path the Nigerian State took to steel development however, contrasted sharply with that of Egypt, Algeria and Tunisia. As noted earlier, the nature of the Nigerian State and its model of capitalism in the steel sector was largely responsible for the inability of the steel sector to lay the foundation for the country's industrialization. Without any industrialization policy in place, and none for the steel sector in particular, the public steel companies came on stream therefore, not necessarily to promote any strategic industrialization, nor provide the basis for endogenizing technology. Rather, steel development as argued earlier, became yet another avenue for those in charge of the State and their local and foreign allies to amass wealth. And as a consequence, no attention was paid to the domestic capacity of the steel companies to replicate machine parts, a capacity on which the industrial progress of the country ought to have rested. DSC and the in-land steel rolling mills, therefore, were intentionally installed without facilities to cast any of the parts of the production plants and furnaces. So too were their foundries fitted with facilities that cannot forge and cast spare parts for the steel plants and heavy industries in the country. At the Ajaokuta Project where upfront payment and gratis have bedeviled its completion, the mistake of DSC was also repeated. That is, intentionally not installing components for producing flats; and other special steel for the purpose $9 \mathrm{f}$ manufacturing machines and other capital goods in the country. Suffice it to note that the trend of the deepening technological dependence that began since colonial period, which the steel companies ought to have reversed as was the case in South Korea, still does not interest the State. Because DSC has no flat steel components, it had to cannibalize most of its production plants to keep very few of them functioning. That is, since most of die production plants and furnaces were built with refurbished machines with an averaging life span of five years, instead of the expected 20 years, more machines were cannibalized leaving i(s capacity utilization drastically reduced. The same sad experience prevailed in (he other steel rolling mills. More details on the steel companies.

As of 1986, that is after only lour years of skeletal operations, DCS had one out of the two matrix 500 modules in the direct reduction plants functioning, the other was out of use. Of the four electric arc furnaces, two were in order while 
the remaining two were broken down. One out of the three concast machines had fallen into disuse. So too were the six moulds casting $129 \mathrm{~mm}$ billets, and the pellet plant. The company had its production capacities already reduced by 50 percent due to maintenance problems. By 1994, none of these production units were functioning and there were no signs of any improvement. .

Of the foreign steel companies that indicated interests in handling the repair of DCS's production plants, none was new to the company. Either they installed part of the plants, thereby supplying the machines/equipment; or they were management consultants. For instance, Voest Alpine, an Austrian company, was only interested in the supply of the parts for the pellet plant which it installed in 1981. So too was the Japanese steel company's interest in supplying spare parts. The steel transnational's were also interested in the conversion of loans for refurbishing the obsolete mills into equipment. The Katsina Steel Rolling Company's aged furnance was built by Kobe Steel only in 1982, and yet it became due for change in 1992; that is, just under nine years of skeletal use. This contrasted sharply with a minimum life span of 25 years for similar furnaces built elsewhere in Japan, Germany, France and the USA. Although Kobe Steel had earlier syndicated a US\$1.8 million loan for the repair of the furnace, it was to be converted into parts and not cash. Because the Katsina Steel Rolling Company had no billets to roll even if the furnace were repaired, Kobe Steel had no opposition to the conversion of the loan into the supply of billets; billets that were produced by its own plant in Kobe, Japan. The aged furnace which was on the verge of collapse, was then used to roll. Lurgi Chemic and Hurten Technik of Germany which installed DSC's crumbled direct reduction plant of DSC in 1981 was also only concerned with the supply of its parts. This is all part of the imperialism of the technical cooperation that the State had signed with the steel transactionals.

Absence of Inter-sectoral Linkage: Products of the steel industry serve as inputs for manufacturing both intermediate and capital goods. Some are, themselves, capital goods. That explains why the steel industry is often described as the 'bedrock of industrialization' since it interlinks other sectors of economy; a role it is yet to play in Nigeria due to the inability of the state to get its ' right fundamentals'. The absence of such linkage has left the Nigeria steel sector largely as 'an enclave' unto itself as both its up-and-down stream operations hardly complement each other. As long as the country's steel sector remains unconnected to other sectors of the economy, Nigeria's intermediate and capital goods-producing companies will continue to be under the control of foreign capital. Let us expantiate on this.

By 1978 when the public steel companies were being built in the country, 
steel consumption per head had already decreased from $80 \mathrm{~kg}$ to $50 \mathrm{~kg}$ following the completion of most of the basic infrastructural amenities like bridges, roads and public buildings in the major urban cities. Yet, the product mix of the steel companies was still mainly structural when they came on stream. Granted, die few private steel rolling companies notably Universal Steel, and Continental Iron and Steel Company both located in Ikeja, Lagos, were unable to meet even three percent of the country's total domestic demand for similar products. However, this was not enough reason for biasing the entire product range of DSC, Ajaokuta and the three rolling mills for simple construction; that is, just rolling out structural steel products like rods and coils. As noted, it was because steel development was not on the agenda of the State. Even then, the coming on stream of the public steel companies did not improve the situation by way of reducing the level of importation as it deepened. The intermediate and capital goods industry, which by the late 1970s, was undeveloped and fragile, did not really grow with the onset of the steel companies. Instead, they were still engaged in 'touching up' the semi-finished products imported from the metropolitan countries.

What is more, the down-stream sector of the steel sector, which is usually commercial in nature, still remains largely in the hands of foreign capital. For instance, of all the steel products like beams, angles and flats that were used in the construction of the country's petroleum refineries, hardly any of them was produced locally. Not even a drilling pipe is rolled out of any of the steel companies in Nigeria. The Machine Tools Limited, Oshogbo, which the State established on the condition that it would depend on the steel company for inputs to produce lathe machines, is not only already dwarfed from onset but its spin-offs, if it takes off at all, are disarticulated. And from the author's current survey of the capital goods industry in Nigeria, no linkage could really be established with the steel sector as of 1995. It was still dependent on imports for its basic raw materials and this will be the trend for years to come. See Table 1 and 2.

It is difficult to decipher the rationale behind steel development by the Nigerian State if the sole purpose is to produce wires and rods to meet only three percent of the local steel consumption in the country. The drastic fall in steel consumption per head from $47 \mathrm{~kg}$ in 1982 when DSC was commissioned, and to about $15 \mathrm{~kg}$ in 1995 was indicative of the fundamental failure of the country' steel industry. 
Table 1

Metal Manufacturers and Fabricators using Intermediate and Capital Good and their Products

\begin{tabular}{|c|c|c|c|c|c|}
\hline company & $\begin{array}{l}\text { Address/owners } \\
\text { hip }\end{array}$ & $\begin{array}{l}\text { Sectoral } \\
\text { Group }\end{array}$ & Sub- sector & $\begin{array}{l}\text { Nature of Basic } \\
R » v \text { Materials and } \\
\text { Source }\end{array}$ & $\begin{array}{l}\text { Products manufactured/ } \\
\text { Broad names }\end{array}$ \\
\hline $\begin{array}{l}\text { Nigeria } \\
\text { Foundries } \\
\text { Ltd. }\end{array}$ & $\begin{array}{l}\text { 1lupeju. Lagos; } \\
\text { private. (1989) }\end{array}$ & $\begin{array}{l}\text { Basic } \\
\text { Metal }\end{array}$ & $\begin{array}{l}\text { foundry } \\
\text { engineering }\end{array}$ & $\begin{array}{l}\text { light steel sheets, } \\
\text { bars, beams and rods; } \\
\text { import dependent }\end{array}$ & $\begin{array}{l}\text { hand operated water } \\
\text { pumps, pressure pipes-for } \\
\text { water/waste drainage, } \\
\text { valves and other industrial } \\
\text { equipments. }\end{array}$ \\
\hline $\begin{array}{l}\text { Roadside } \\
\text { Engineering } \\
\& \text { Foundry }\end{array}$ & $\begin{array}{l}\text { llupeju, Lagos: } \\
\text { private. (1952) }\end{array}$ & $\begin{array}{l}\text { Basic } \\
\text { Metal }\end{array}$ & $\begin{array}{l}\text { foundry } \\
\text { engineering' }\end{array}$ & $\begin{array}{l}\text { recycling ferrous and } \\
\text { non-ferrous scraps; } \\
\text { import dependent }\end{array}$ & $\begin{array}{l}\text { casting hoi!; ferrous and } \\
\text { non-ferrou- metals; based } \\
\text { on samples and } \\
\text { specifications }\end{array}$ \\
\hline $\begin{array}{l}\text { Anneco-Arewa } \\
\text { Metal } \\
\text { Construction } \\
\text { T } f A \\
\text { LM. }\end{array}$ & $\begin{array}{l}\text { Kaduna } \\
\text { public/private; } \\
\text { (ratio not } \\
\text { available) }\end{array}$ & $\begin{array}{l}\text { Basic } \\
\text { Metal }\end{array}$ & $\begin{array}{l}\text { construction } \\
\text { engineering/m } \\
\text { etal } \\
\text { manufacturing }\end{array}$ & $\begin{array}{l}\text { light/medium steel } \\
\text { flats; import } \\
\text { dependent. }\end{array}$ & $\begin{array}{l}\text { agric silos; soft beer } \\
\text { earners: bodies of tankers } \\
\text { and trailers; surface and } \\
\text { underground storage } \\
\text { tanks. }\end{array}$ \\
\hline $\begin{array}{l}. \text { Inchor } \\
\text { Products Ud. }\end{array}$ & $\begin{array}{l}\text { Ike|a_1 .agos. } \\
\text { private: } \\
(1978 ;\end{array}$ & $\begin{array}{l}\text { Basic } \\
\text { Metal }\end{array}$ & $\begin{array}{l}\text { construction } \\
\text { engineering/m } \\
\text { etal } \\
\text { manufacturing } \\
\text { / }\end{array}$ & $\begin{array}{l}\text { special steel, bars } \\
\text { and rods, ferrous and } \\
\text { non-ferrous alloys; } \\
\text { and their scraps; } \\
\text { import -dependent. }\end{array}$ & $\begin{array}{l}\text { moulds for plastic and } \\
\text { aluminium industries: } \\
\text { machine parts such as } \\
\text { shafts, bearings and gears: } \\
\text { fabricates simple } \\
\text { machines and equipment } \\
\text { according to specification } \\
\end{array}$ \\
\hline $\begin{array}{l}\text {.Agricultural } \\
\text { Machinery } \\
\text { Manufacturin } \\
\text { gCo. I Ad. } \\
\end{array}$ & $\begin{array}{lll}\text { Ketu. I age is. } \\
\text { private }(19 \mathrm{X} 4)\end{array}$ & $\begin{array}{l}\text { Basic } \\
\text { Metal }\end{array}$ & $\begin{array}{l}\text { Engineering } \\
\text { and fabrication }\end{array}$ & $\begin{array}{l}\text { light medium steel } \\
\text { flats, bars and rods; } \\
\text { import dependent }\end{array}$ & $\begin{array}{l}\text { spades, shovels, matchets } \\
\text { rakes and travel; brand } \\
\text { name is Bull. }\end{array}$ \\
\hline $\begin{array}{l}\mathrm{BACO} \\
\text { Co. lid }\end{array}$ & $\begin{array}{ll}\text { Aha. } & \text { private. } \\
(1972) & \end{array}$ & $\begin{array}{l}\text { Basic } \\
\text { Metal }\end{array}$ & fabrication & $\begin{array}{l}\text { light/medium steel } \\
\text { flats, bars and rods. } \\
\text { import dependent. }\end{array}$ & $\begin{array}{l}\text { underground tanks, door } \\
\text { hinges, shoe shanks, bed } \\
\text { hooks; brand name is } \\
\text { BACO. }\end{array}$ \\
\hline $\begin{array}{l}\text { Hocsch Pi pie } \\
\text { Mills. Nig } \\
\text { Ud }\end{array}$ & $\begin{array}{l}\text { Ikeja, Ijigi* } \\
\text { private. } 40 ., \\
\text { Nigeria } \\
60 \% \text { foreign } \\
(1974)\end{array}$ & $\begin{array}{l}\text { Basic } \\
\text { metal } \\
\text { engineeri } \\
\text { ng }\end{array}$ & fabrication & $\begin{array}{l}\text { light steel flats } \\
\text { (galvanized); import } \\
\text { dependent }\end{array}$ & $\begin{array}{l}\text { galvanised steel buckets. } \\
\text { storage/waste bins, metal } \\
\text { mesh; brand name is } \\
\text { IIOKSCH. }\end{array}$ \\
\hline 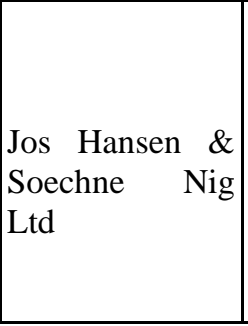 & 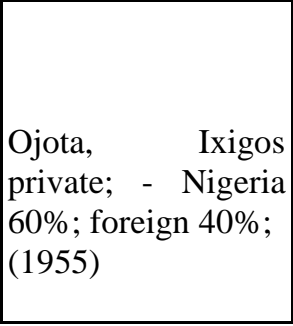 & $\begin{array}{l}\text { Basic } \\
\text { metal } \\
\text { engineerin } \\
\mathrm{g}\end{array}$ & fabrication & $\begin{array}{l}\text { light and medium steel } \\
\text { flats non- } \\
\text { ferrous metals, cables; } \\
\text { import dependent }\end{array}$ & $\begin{array}{l}\text { sale of imported } \\
\text { centrifugal pumps, hand } \\
\text { operated pumps, and } \\
\text { fabrication of their parts and } \\
\text { rewinding ol electric } \\
\text { motors; brand name is } \\
\text { KSB. }\end{array}$ \\
\hline
\end{tabular}


88 Annals of the Social Science Council of Nigeria, No. 9, January-December, 1997

\begin{tabular}{|c|c|c|c|c|c|}
\hline \begin{tabular}{|l|} 
Kew \\
Metalworks \\
Ltd
\end{tabular} & $\begin{array}{l}\text { Ikeja, } \\
\text { private; (1976). }\end{array}$ & $\begin{array}{l}\text { Basic } \\
\text { metal }\end{array}$ & fabrication & $\left|\begin{array}{llr}\text { Special } & \text { light } & \text { and } \\
\text { medium } & \text { steel } & \text { bars, } \\
\text { rods } & \text { and } & \text { flats; } \\
\text { import dependent. }\end{array}\right|$ & $\begin{array}{|lr|}\text { steel } & \text { window/doer } \\
\text { frames? } & \text { constructional } \\
\text { products } & \text { such as bars }-\mathrm{J} \\
\mathrm{Z}, \mathrm{T} \text { and angles }\end{array}$ \\
\hline \begin{tabular}{|l} 
Light \\
Machines \\
Ind.Nig.Ltd
\end{tabular} & $\begin{array}{l}\text { Ikeja, } \quad \text { Lagos; } \\
\text { private; (1971). }\end{array}$ & \begin{tabular}{|l|} 
Basic \\
metal/ \\
engineeri \\
ng
\end{tabular} & $\begin{array}{l}\text { fabrication/ } \\
\text { engineering } \\
\text { foundry }\end{array}$ & $\begin{array}{|lrr|}\text { light } & \text { and } & \text { medium } \\
\text { steel } & \text { flats: } & \text { non- } \\
\text { ferrous } & \text { metals } & \text { and } \\
\text { alloys: } & \text { import } \\
\text { dependent. } & \\
\end{array}$ & $\begin{array}{l}\text { steel metals for forming } \\
\text { bodies: spare parts for } \\
\text { machines and moulds }\end{array}$ \\
\hline \begin{tabular}{|l|} 
Metal \\
Furniture Nig. \\
Ltd
\end{tabular} & $\begin{array}{l}\text { Ikeja, } \\
\text { private; (1962). }\end{array}$ & $\begin{array}{l}\text { Basic } \\
\text { Metal }\end{array}$ & fabrication & \begin{tabular}{|lrr} 
Special light & and \\
medium & steel & bars, \\
rods and flats; \\
import dependent.
\end{tabular} & steel office equipments \\
\hline \begin{tabular}{|l|} 
Modem \\
Engineering \\
Works Ltd
\end{tabular} & \begin{tabular}{|l} 
Sango \\
private;
\end{tabular} & \begin{tabular}{|l|} 
Basic \\
Metal/ \\
Engineer \\
ing \\
\end{tabular} & fabrication & 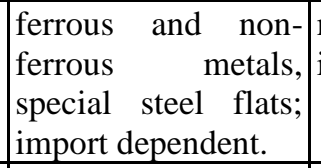 & $\begin{array}{l}\text { moulds for } \\
\text { industries. }\end{array}$ \\
\hline \begin{tabular}{|l|} 
Nigerian Gas \\
Cylinders \\
Coy. Ltd \\
\end{tabular} & $\begin{array}{l}\text { Agodi, Ibadan; } \\
\text { private; (1977). }\end{array}$ & $\begin{array}{l}\text { Basic } \\
\text { metal }\end{array}$ & fabrication & $\begin{array}{l}\text { special flat steel; } \\
\text { import dependent }\end{array}$ & $\begin{array}{l}\text { gas cylinders for both } \\
\text { industrial and domestic } \\
\text { uses. }\end{array}$ \\
\hline $\begin{array}{|lr|}\text { Pressed } & \text { Metal } \\
\text { Works } & \text { Coy. } \\
\text { Ltd } & \\
\end{array}$ & $\begin{array}{ll}\text { Ijora, } & \text { Lagos; } \\
\text { private } & -40 \% \\
\text { Nigeria; } & 60 \% \quad: \\
(1960) . & \end{array}$ & $\begin{array}{l}\text { Basic } \\
\text { Metal }\end{array}$ & $\begin{array}{l}\text { fabrication } \\
r\end{array}$ & $\begin{array}{ll}\text { light and medium } \\
\text { steel flats: import } \\
\text { dependent. }\end{array}$ & \begin{tabular}{|lr} 
vehicle $\quad$ bodies & (pmv \\
commercial); & storage \\
tanks $\quad(\mathrm{pmv}$ & structures) \\
and & agricultural \\
implements & (pmv \\
agricultural). & \\
\end{tabular} \\
\hline \begin{tabular}{|l|} 
SCOAIARD \\
(A Division of \\
SCOA Nig. \\
Ltd) \\
\end{tabular} & \begin{tabular}{|lr} 
Lagos; & private \\
and public; $60 \%$ \\
Nigeria; & $40 \%$ \\
foreign. & \\
\end{tabular} & $\begin{array}{l}\text { Basic } \\
\text { metal }\end{array}$ & fabrication & $\begin{array}{|lr|}\text { special } & \text { steel, } \\
\text { and } & \text { mediuml- } \\
\text { flats; } & \text { import } \\
\text { dependent. } & \\
\end{array}$ & $\begin{array}{l}\text { bodies for cool vehicle- } \\
\text { and refuse bins. }\end{array}$ \\
\hline $\begin{array}{l}\text { SETEMEC } \\
\text { Ltd }\end{array}$ & \begin{tabular}{|lr} 
Isolo, & Lagos; \\
private & $-40 \%$ \\
Nigeria; & $60 \%$ \\
fiweign; $<1973)$ \\
\end{tabular} & $\begin{array}{l}\text { Basic } \\
\text { metal }\end{array}$ & fabrication & 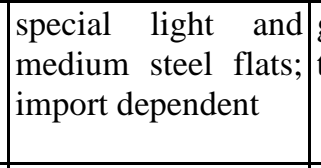 & $\begin{array}{l}\text { gas cylinders and LPG } \\
\text { tank*;: }\end{array}$ \\
\hline $\begin{array}{l}\text { Steelworks } \\
\text { Ltd }\end{array}$ & \begin{tabular}{|lr} 
Oluyole, & Ibadan; \\
private; & $73 \%$ \\
Nigeria; & $27 \%$ \\
foreign; & (1963). \\
\end{tabular} & $\begin{array}{l}\text { Basic } \\
\text { metal }\end{array}$ & fabrication & 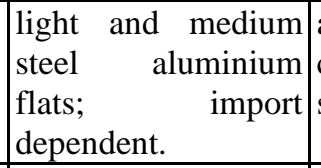 & $\begin{array}{l}\text { aluminium roofing, } \\
\text { cladding and construction } \\
\text { steel products. }\end{array}$ \\
\hline $\begin{array}{|ll|}\text { Baltic } & \text { Group } \\
\text { Ltd } & \end{array}$ & $\begin{array}{lr}\text { Benin } & \text { City, } \\
\text { private } & 100 \% \\
\text { Nigerian; } & (1975) .\end{array}$ & $\begin{array}{l}\text { Basic } \\
\text { Metal }\end{array}$ & $\begin{array}{l}\text { engineering/ } \\
\text { fabrication }\end{array}$ & $\left|\begin{array}{l}\text { Light medium steel } \\
\text { flats, bars and rods; } \\
\text { import dependent. }\end{array}\right|$ & $\begin{array}{|ll|}\text { bakery } & \text { equipments, } \\
\text { hospital } & \text { equipments, } \\
\text { mechanical } & \text { parts; } \\
\text { name is } & \text { bALTIC } \\
\end{array}$ \\
\hline $\begin{array}{l}\text { Crittal-Hope } \\
\text { Nig. Ltd }\end{array}$ & $\begin{array}{lr}\text { Mushin, } & \text { Lagos; } \\
\text { private; } & 50 \% \\
\text { Nigeria; } & 50 \% \\
\text { foreign; } & (1958) .\end{array}$ & $\begin{array}{l}\text { Basic } \\
\text { Metal }\end{array}$ & $\begin{array}{l}\text { engineering/ } \\
\text { fabrication }\end{array}$ & $\begin{array}{l}\text { Light medium steel } \\
\text { and aluminium flats } \\
\text { and rods: import } \\
\text { dependent }\end{array}$ & $\begin{array}{l}\text { steel and aluminium door } \\
\text { and window frames; } \\
\text { louvre channels. }\end{array}$ \\
\hline
\end{tabular}




\begin{tabular}{|c|c|c|c|c|c|}
\hline $\begin{array}{l}\text { Christor } \\
\text { Works Nig. } \\
\text { Ltd. }\end{array}$ & $\begin{array}{l}\text { Oshodi, Lagos; } \\
\text { private; (1980). }\end{array}$ & $\begin{array}{l}\text { Basic } \\
\text { metal }\end{array}$ & fabrication & $\begin{array}{l}\text { light medium } \\
\text { steel flats; import } \\
\text { dependent. }\end{array}$ & \begin{tabular}{|lr} 
silencers and mufflers \\
for & vehicles, \\
generators & and \\
engines. & \\
\end{tabular} \\
\hline $\begin{array}{l}\text { Crocodile } \\
\text { Matchets } \\
\text { Nig. Ltd. }\end{array}$ & $\begin{array}{ll}\text { Trans Amadi, } & \text { Am } \\
\text { Port-Hareourt; } & \\
\text { private; } & 40 \% \\
\text { Nigeria; } & 60 \% \\
\text { foreign; } & \\
\text { (1965). } & \\
\end{array}$ & $\begin{array}{l}\text { Basic } \\
\text { metal }\end{array}$ & fabrication & $\begin{array}{l}\text { light steel flats; } \\
\text { import } \\
\text { dependent. }\end{array}$ & $\begin{array}{l}\text { cutlass; brand name is } \\
\text { CROCODILE }\end{array}$ \\
\hline $\begin{array}{l}\text { Ekene Dili } \\
\text { Chukwu } \\
\text { (Steel } \\
\text { Structures) } \\
\text { Ltd. } \\
\end{array}$ & $\begin{array}{l}\text { Awada, } \\
\text { Onitsha; } \\
\text { private; (1976) }\end{array}$ & $\begin{array}{l}\text { Basic } \\
\text { metal }\end{array}$ & $\begin{array}{l}\text { Engineering } \\
\text { fabrication }\end{array}$ & $\begin{array}{l}\text { light and medium } \\
\text { steel flats; import } \\
\text { dependent. }\end{array}$ & $\begin{array}{l}\text { kerosene and petrol } \\
\text { tanks; bodies for } \\
\text { tippers, trailers, refuse } \\
\text { and loaders. }\end{array}$ \\
\hline $\begin{array}{l}\text { Eldleoseka } \\
\text { Investment } \\
\text { Co. Ltd. }\end{array}$ & $\begin{array}{l}\text { 'Nkpftr, } \\
\text { Onitsha; } \\
\text { private; (1983) }\end{array}$ & $\begin{array}{l}\text { Basic } \\
\text { metal }\end{array}$ & fabrication & $\begin{array}{l}\text { light/medium } \\
\text { steel and } \\
\text { aluminium flats; } \\
\text { rods and coils; } \\
\text { local and import } \\
\text { dependent. }\end{array}$ & $\begin{array}{l}\text { wheel barrow, wire } \\
\text { fence and rivet nails. }\end{array}$ \\
\hline
\end{tabular}

Sources. Author's Field Work: University Steel Company, Ikeja - Lagos.

July, August and Manufacturers Association of Nigeria, Ikeja - Lagos. September 1994 The Various Industrial Areas of Lagos.

The Industrial .Areas of Otta, Ogun State.

Nigerian chamber of Commerce, Agriculture. Mines. Maryland. Lagos

Federal office of Statistics, Lagos. 
90 Annals of the Social Science Council of Nigeria, No. 9, January-December, 1997

Table II

\begin{tabular}{|l|l|l|l|l|l|}
\hline \multicolumn{6}{|c|}{ Product Mix of Public and Private Steel Companies in Nigeria; 1982 - 1992 } \\
\hline & Method of Production (Metric Tonne*) & \multicolumn{2}{|l|}{ Preijnet Mb (Metric Tonjua) } \\
\hline Year & $\begin{array}{l}\text { Direct } \\
\text { Production }\end{array}$ & $\begin{array}{l}\text { Electric Arc } \\
\text { Furnace }\end{array}$ & $\begin{array}{l}\text { Continuous } \\
\text { Casting } \\
\text { (Billets) }\end{array}$ & $\begin{array}{l}\text { Concrete } \\
\text { Reinforcing } \\
\text { Bars }\end{array}$ & $\begin{array}{l}\text { Other Ban } \\
\text { and Light } \\
\text { Shapes }\end{array}$ \\
\hline 1982 & 73,000 & 90,000 & 81,000 & 12,000 & 1,000 \\
\hline 1983 & 156,000 & 182,000 & 163,000 & 330,000 & 220,00 \\
\hline 1984 & 142,000 & $229,000-$ & 162,000 & 271,000 & 68,000 \\
\hline 1985 & 242.000 & 321,000 & 332,000 & 413,000 & 103,000 \\
\hline 1986 & 109,000 & 200,000 & 126,000 & 202,000 & 67,000 \\
\hline 1987 & 131,000 & 184,000 & 130,000 & 231,000 & 77,000 \\
\hline$! 988$ & 132,000 & 234.000 & 139,000 & 212.000 & 71,000 \\
\hline 1989 & 124,000 & 213,000 & 128,000 & & - \\
\hline 1990 & 112,000 & 220,000 & 139.000 & & - \\
\hline 1991 & 108,000 & 250,000 & 109,000 & & - \\
\hline
\end{tabular}

Sources: Author's Field work: Delta Steel Company (Production Department) Oshogbo. Jos and Kaduna Steel Rolling Companies (Production Department - field)

Universal Steel Company, Ikeja, Lagos; Continental Iron and Steel Company Ikeja- Lagos; and other private steel companies.

Metal Bulletin, 1989 - 1991 issues

Annual Abstract of Statistics (Lagos: FOS) 1990 \& 1991 editions 
The Nigerian Steel Sector in the Global Steel Industry 91

\section{Acute Financial Constraints:}

Ajaokuta, DSC and the three Steel Rolling Mills were all political projects in the sense that economic viability did not really enter into their establishment. That explains in part why the structural crisis in the economy as of 1979 did not deter the Shagari Administration from embarking upon an ambitious steel development. As a result, steel development lacked all the seriousness and purposefulness it required. Thus, barely six months after commissioning DSC for instance, it was so cash-strapped that it could not import spare parts for maintaining its plants resulting in the continuous cannibalization of its machines from 1982 till 1995 when it was closed indefinitely. So too did acute shortage of raw material profoundly impacted on its capacity utilization, which averaged three percent of its one million metric tonnes of crude steel capacity; and fv» e percent of its 960,000 tonnes of billets annual capacity. The rolling mills were lot spared of chronic financial crisis too.

By 1986 when the State adjusted, the steel companies could no longer be financed. Commercializing and privatizing them under the World Bank/IMF-directed adjustment was considered the next option for bailing them out of the financial crisis. But the conditions of financial assistance laid down by the Bank and Fund did not appeal to the State, as such conditions would totally retrench it (the state) from the steel sector while bringing in foreign steel companies to take full control. To the Bank, it was obvious that the State alone could not bear the burden of financing the steel companies. Privatizing them meant that it (state) had to abandon its earlier social service position of merely underwriting the financial cost of running the steel companies, and to resign to a regulatory function. Funding of the steel companies, the Bank/Fund insisted, had to comply with the rules of capitalist financing: to make profits. All was to help reproduce the mode of capitalist accumulation in the global steel industry. The State's recent thinking to contract-lease the steel companies to the steel transnational was therefore because it ran out of options on the way forward.

However, under the leasing arrangement, the state still wanted to remain as the sole owner of the steel companies, while their actual operation and management were to be in the hands of foreign capitals for a minimum lease period of 15 years; a time they (steel TNCs) thought was enough to have recovered their cost, and perhaps, begin to make profit, but leaving the State further incapacitated and the steel companies worse off.

As an imperialist plot, contract-leasing is designed to deepen the financial crisis and technological dependence of the public: steel companies on the steel TNCs. As explained earlier, the global steel market slided into market glut in 1975. 
92 Annals of the Social Science Council of Nigeria, No. 9, January-December, 1997 ,

The installation of refurbished machines in the steel companies in the countries of Africa, not least Nigeria, was meant to create automatic market for the steel transnational, knowing fully well that the life span of these machines was already shortened as they have been used before. Again, it is these re-conditioned machines/parts that will, most likely, be used during the contrast lease period so that by the end of the proposed lease period, they would be due again for replacement, making it all the more difficult for the companies to recover. That is not all, inputs for steel production especially iron ore for which Nigeria has local deposits estimated about 5 billion metric tonnes and of high ferrous content, would be stopped as the operating steel TNCs insist on bringing in iron ore and other consumables from their home countries. The implication of this for Nigeria is that the local steel industry will be 'killed' since the interest of foreign capital is to export finished steel products to Nigeria as the experience of Qatar has shown.

As of 1996, the expectations of the State from contract-leasing and other forms of raising funds externally to finance the ailing steel companies were yet to be realized. Voest Alpine, which had earlier indicated interest in the complete take over of DSC, pulled out of the deal. Church gate, a conglomerate of Asian merchant capital in Nigeria, capitalising on its long standing business links with the hegemonic class of the Nigerian State and the late General Sani Abacha, wanted to buy over DSC but became reluctant, and finally declined to continue with the transaction. Not even the conversion of loans into spare parts could change the mind of foreign capital. Rather, they insisted on cash dealing. So, too, was Kobe Steel. No clear foreign interests were indicated on Jos and Oshogbo Steel Rolling Mills, or the National Iron Ore Mining Project, Itakpe. The question is: why the sudden back out?

Two specific reasons may explain it. First, the books of the steel companies were in serious deficits and, therefore, did not appeal to any would-be foreign investors. For instance, local contractors were owed 4 billion; about 1,5 billion was owed to the National Petroleum (NNPC) for the supply of gas to fire the plants. About 90 billion was needed to revamp the company's broken-down production plants and another 60 billion was needed for guaranteeing steady supply of iron ore and other consumables for at least one year, For each of the three rolling mills, 60 billion was needed to bring them back to work, all totalling 180 billion. In all, a total of about 363.5 billion was required to turnaround the ailing public steel companies; an amount neither the State and local private capital could provide, nor any foreign steel company was actually prepared to risk.

Second, and perhaps more important, was the unwillingness of the Nigerian State to undermine its real intention of setting up the steel companies: that of serving as an avenue for plum political appointments and amassing wealth. Though 
The Nigerian Steel Sector in the Global Steel Industry 93

contract-leasing might guarantee regular rents accruing to the State, its control over such sector would be lost to the steel transnational companies. The State, therefore, was uncertain as to how to really tackle the financial crisis that its steel companies are faced with without losing absolute political control and jeopardizing its own capitalism.

As of December 1995, all the public steel companies remained shut indefinitely and mired in serious financial crisis, problems that continued into 1996 and with little or no hope of recovery. The only latest development in the steel sector, since then, was that the steel companies might not be leased to foreign capital ostensibly for political reasons. But that was only at the risk of scrapping them or retained as monuments of failure.

\section{Concluding Remarks}

The State has proved incapable of managing the country's steel sector. The inherent contradictions in its approach to the development of iron and steel have continued to deepen. If the steel sector is to recover, then the State should be concerned with a regulatory role, while entrusting the management of the steel companies particularly DSC and Ajaokuta, which are integrated plants, to an indigenous holding company. The Rolling Mills, which are precisely the commercial ends of the steel industry should be privatized with preference given to the steel workers and the local steel merchants. That would help develop an industrial domestic bourgeois class; a class, which if it really emerges strongly, would complement the country's industrial development.

\section{References}

Based on the author's field trips to some capital goods producing companies in Lagos, Ibadan, Kano in 1994.

1. Baran, P. (1957), The Political Economy of Grouth (New York, MRP)

2. $\quad$ Frank, A.G. (1977), Imperialism and Unequal Development (New York, Monthly Review Press); and (1967) Capitalism and Underdevelopment in Latin American: Historical Studies of Chile and Brazil (New York, MRP)

3. $\quad$ Hatch Report (1988) "Steel Sub-Sector Study in Nigeria" Canada.

4. Kilby, P. (1969), Industrialization in an Open Economy: Nigeria, 1945-1960 (Cambridge, Cambridge University Press).

5. Metal Bulletin, (1975 through 1986).

6. Nnoli O. (1981 ed.) Path to Nigeria's Development (Dakar, CODESRIEA 1981).

7. Rodney, W. (1976), How Europe Underdeveloped Africa (Dar-Es-Salaam, Tanzania Publishing House).

8. UNIDO (1989) Atlas of African Industry: Iron and Steel.

9. Yachir, F. (1986) The World Steel Industry Today (London/Tokyo, Zed/United Nations University). 